\title{
Koncepcja smart city a COVID-19. Wykorzystanie nowych mediów w obliczu pandemii
}

\begin{abstract}
Streszczenie
Celem artykułu jest sprawdzenie wykorzystania potencjału mediów u przestrzeni miejskiej w obliczu pandemii COVID-19 na przykładzie największego miasta w Polsce - Warszawy. Autor dokonuje analizy tak zwanych nowych mediów, które poustały na bazie technologii informacyjnych i komunikacyjnych, zuracając uwagę zarówno na kanał (infrastruktura miękka), jak i środek przekazu (infrastruktura tuarda). Główną metodą badawczą jest studium przypadku, która umożliwia określenie dobrych i złych praktyk przy wykorzystywaniu nowych mediów w mieście oraz celów strategicznych analizowanych miast. Badanie jest oparte na analizie literatury, dokumentów strategicznych, broszur oraz stron internetowych. Hipotezą badauczą jest stwierdzenie, że władze miejskie Warszawy, dostosourjąc strategię smart city u czasie pandemii, rozwijają system komunikacyjny oparty na platformie internetowej. Wyniki badań pokazują, że władze miejskie w Warszawie realizują koncepcję smart city poprzez wykorzystywanie nowych form mediów i technologii, które są zarówno celami, jak i narzędziami jej implementacji. W czasie pandemii poszczególne media cyfrowe u mieście zostały rozwinięte o treści poświęcone COVID-19, a działania dedykowane informowaniu i komunikacji z mieszkańcami są podejmowane poprzez platformę Warszawa 19115.
\end{abstract}

Słowa kluczowe: smart city, media u smart city, nowe media, media u mieście.

\section{Smart city and COVID-19. Using new media in the face of the pandemic}

\section{Abstract}

This article aims at examining the use of the potential of media in the urban space in the face of the COVID-19 pandemic on the example of the largest city in Poland - Warsaw. The author analyses the so-called new media, which were created on the basis of information and communication technologies, paying attention to both the channel (soft infrastructure) and the medium (hard infrastructure). The main research method is the case study of the mentioned city, which allows identifying good and bad practices in the use of new media in the city and the strategic objectives of the analysed cities. The study is based on the analysis of literature, strategic documents, brochures and websites. The research hypothesis is that the city authorities of Warsaw, adapting the smart city strategy during the pandemic, develops a communication system based on the Internet platform. The research results show that the municipal authorities in Warsaw are implementing the smart city concept by using new forms of media and technology as both 
targets and tools for its implementation. During the pandemic, the city's various digital media were developed with content dedicated to COVID-19, and activities dedicated to informing and communicating with residents are undertaken through Warszawa 19115 platform.

Keywords: smart city, media in smart city, new media, media in the city.

\section{Wprowadzenie}

Media i prawidłowy przepływ informacji odgrywają istotną rolę, nie tylko w komunikacji, lecz także w usprawnianiu procesów decyzyjnych, zarządzaniu i rozwoju obszarów miejskich. Szczególnie nowe media, powstające na bazie technologii informacyjnych i komunikacyjnych (information and communication technologies, ICT), umożliwiają aktyune zaangażowanie mieszkańców miast w wiele procesów miejskich: partycypację, interakcję, zarządzanie, współtuorzenie, informowanie itd. Są one wykorzystywane w każdym aspekcie funkcjonowania mieszkańca miasta, od socjalizacji, kultury i rozrywki, po usługi zdrowotne i transport, do edukacji i biznesu. Najnousze technologie mają na celu stworzenie efektywnego i przyjaznego obywatelom środowiska miejskiego, optymalizując funkcjonowanie i jakość życia mieszkańcóu miast.

Nowe media oraz technologie są kluczowymi obszarami działania w koncepcji smart city, stając się zarówno celem, jak i narzędziem jej realizacji. Idea ta jest używana do opisywania innowacyjnych rozuiązań, których celem jest stworzenie wydajnego i elastycznego „miasta przyszłości”. Smart city to miasto, które wykorzystuje nowe technologie do poprawy jakości życia mieszkańców i efektywnego zarządzania miastem. Efektem udrażania strategii smart city ma być nie tylko rozwój miasta, na przykład w dziedzinie ekonomii lub zasobów ludzkich, lecz także dostosouywanie się do dynamicznie zmieniającego się środowiska zewnętrznego, zapobieganie zagrożeniom oraz reagowanie na kryzysy. Wielu badaczy podkreśla rolę wykorzystania ICT w procesie implementacji strategii smart city ${ }^{1}$. Innowacyjne i technologiczne rozwiązania są wdrażane $u$ strukturę miejską $w$ postaci między innymi platform, aplikacji, siatek sensorycznych czy infrastruktury mediów, umożliwiając tworzenie nowych sposobów komunikacji pomiędzy władzami miejskimi, mieszkańcami i maszynami². Przykładowo smartfony, smart zegarki czy interaktyune ekrany u przestrzeni miejskiej umożliwiają korzystanie z platform i aplikacji miejskich, a rozwiązania sensoryczne instalowane w środkach transportu miejskiego czy domach działają dzięki oprogramowaniom i łączności bezprzewodowej.

Ogólnoświatowa pandemia wywołana wirusem SARS-CoV-2 zmieniła radykalnie wiele obszarów funkcjonowania jednostki w wymiarze prywatnym, zawodowym,

\footnotetext{
${ }^{1}$ R. Giffinger et al., Smart Cities. Ranking of European medium-sized cities, Vienna University of Technology, Vienna 2007. Zobacz także: A. Haidine et al., The Role of Communication Technologies in Building Future Smart Cities [w:] Smart Cities Technologies, eds. I. Nunes Da Silva, R. Andrade Flauzino, Intechopen, London 2016.

${ }^{2}$ M. Miller, The Internet of Things. How Smart TVs, Smart Cars, Smart Homes, and Smart Cities Are Changing the World, Pearson Education, Indianapolis 2015.
} 
obywatelskim, ekonomicznym czy kulturowym. Ogłoszenie światowej pandemii w marcu 2020 roku przez Światową Organizację Zdrowia (World Health Organization, WHO) ${ }^{3}$ oznaczało uprowadzenie licznych restrykcji związanych nie tylko z zakazem wjazdów i wyjazdów obywateli na terytorium danego kraju, lecz także z przemieszczaniem się i organizowaniem spotkań przez obywateli wewnątrz kraju. Liczne ograniczenia zuiązane z zakazami, zasadami i zaleceniami rządów w poszczególnych krajach, dotyczące między innymi przemieszczania się, utrzymywania dystansu społecznego czy zasłaniania ust i nosa, upłynęły na zmiany w sposobie komunikacji międzyludzkiej, zmieniając środek ciężkości z komunikacji bezpośredniej w świecie realnym na komunikację drogą cyfrową. Zułaszcza w miastach, które są gęsto zaludnionymi obszarami, będącymi ośrodkami urzędowymi, gospodarczymi, biznesowymi i kulturowymi, władze miejskie stanęly przed uyzwaniem dostosowania się do nowej, pandemicznej rzeczywistości. Oprócz działań zapobiegających rozprzestrzenianiu się koronawirusa, władze miejskie muszą podejmować kroki w kierunku optymalizacji procesów komunikacyjnych w mieście, które umożliwiają przekazywanie bieżących informacji mieszkańcom, korzystanie $\mathrm{z}$ usług miejskich (w tym administracji), funkcjonowanie gospodarki i edukacji oraz zbieranie danych z tkanki miejskiej w celu efektywnego zarządzania miastem.

Właściwie zaprojektowana infrastruktura mediów w smart city, składająca się z odpowiednich oprogramowań i narzędzi, optymalizuje procesy komunikacyjne w mieście w czasie kryzysu, jakim jest pandemia COVID-19. W procesie udrażania strategii smart city poprzez poszczególne miasta kluczowy jest nacisk na możliwości komunikacji cyfrowej, która ma za zadanie ułatwić życie mieszkańcom oraz zarządzać obszarem miejskim - w czasie „spokoju” i zagrożenia. Dlatego ważne jest określenie celów strategicznych miast, dotyczących rozwijania nowych mediów, które zostały wdrożone przed pandemią, jak też zaktualizowane w czasie jej trwania.

\section{W kierunku smart city}

Obecnie obszary miejskie zamieszkuje 55\% światowej populacji ludzkiej i szacuje się, że do 2050 roku odsetek ten wzrośnie do 68\% ${ }^{4}$. Rosnąca liczba ludności miast jest wyzwaniem dla władz miejskich, które mają za zadanie stworzyć środowisko sprzyjające rozwojowi społecznemu, ekonomicznemu i kulturowemu, przy uwzględnieniu postępujących przemian technologicznych oraz różnorodności etnicznych, językowych, religijnych i socjo-ekonomicznych. Celem strategicznym jest również zapewnienie ładu społecznego, bezpieczeństwa mieszkańców oraz zapobieganie sytuacjom stwarzającym stan zagrożenia lub kryzysu. Nowe media i ICT pozwalają usprawnić funkcjonowanie

\footnotetext{
${ }^{3}$ WHO, WHO announces COVID-19 outbreak a pandemic, https://www.euro.who.int/en/ health-topics/health-emergencies/coronavirus-COVID-19/news/news/2020/3/who-announces-COVID-19-outbreak-a-pandemic (dostęp: 8.02.2021).

${ }_{4}^{4} 68 \%$ of the world population projected to live in urban areas by 2050, says UN, https://www. un.org/development/desa/en/news/population/2018-revision-of-world-urbanization-prospects. html (dostęp: 21.01.2021).
} 
obywateli u mieście. Dzięki interaktywności i integracji danych, noue media umożliwiają interakcje władz lokalnych z mieszkańcami, a także monitorowanie bieżących zdarzeń zachodzących na obszarze miejskim. Ze względu na dynamicznie zmieniające się otoczenie technologiczne i poustawanie nowych modeli komunikacyjnych, media we współczesnych miastach są coraz częściej analizowane przez pryzmat koncepcji smart city.

Michael O'Grady i Gregory O’Hare podkreślają, że nie istnieje jedna, uniwersalna definicja smart city ${ }^{5}$. Jest to pojęcie wieloznaczeniowe i wielowymiarowe, które rozpatruje się $\mathrm{w}$ kontekstach społecznym, ekonomicznym i politycznym danego miasta ${ }^{6}$, dlatego też pouinno być ono badane poprzez uwzględnienie wielu różnych elementów? Głównych czynników powodujących rozpowszechnienie omawianej koncepcji można dopatrywać się w dyfuzji urządzeń mobilnych i internetu oraz ochronie środowiska naturalnego i zapobieganiu nadmiernej konsumpcji na terenach miejskich ${ }^{8}$. W ciągu lat wykształciło się wiele pojęć odnoszących się potencjału wykorzystania ICT w przestrzeni miejskiej, takich jak wired city ${ }^{9}$, cyber city, digital city, intelligent city czy ureszcie smart city ${ }^{10}$. Termin smart city charakteryzuje wykorzystanie smartfonów, urządzeń mobilnych, sensorów, smart liczników, oprzyrządowania utrzymującego smartness miasta oraz smart środowisko ${ }^{11}$.

Rozpatrując smart city w ujęciu technologicznym, J. Ramon Gil-Garcia rozumie to pojęcie jako miasto wykorzystujące ICT do integracji danych, informacji, procesów, podmiotów i infrastruktury fizycznej w celu polepszenia jakości życia mieszkańców i całego społeczeństua ${ }^{12}$. Doug Washburn wraz z innymi twierdzi, że smart city opiera się na wykorzystaniu technologii smart computing, która spowoduje, że elementy infrastruktury i usług miejskich (np. administracja, edukacja, bezpieczeństwo) staną się interpołączone, wydajne i inteligentne ${ }^{13}$. Michael Batty wraz z innymi badaczami

${ }^{5}$ M. O’Grady, G. O’Hare, How Smart Is Your City?, „Science” 2012, Vol. 335, No. 3, s. 1581-1582. ${ }^{6}$ V. Albino, U. Berardi, R.M. Dangelico, Smart Cities: Definitions, Dimensions, Performance, and Initiatives, „Journal of Urban Technology” 2015, Vol. 22, No. 1, s. 3-21.

${ }^{7}$ Smarter as the New Urban Agenda. A Comprehensive View of the 21st Century City, eds. J.R. Gil-Garcia, T.A. Pardo, T. Nam, Springer, Heidelberg 2015.

${ }^{8}$ I. Oberti, A.S. Pavesi, The Triumph of the Smart City, ,Techne. Journal of Technology for Architecture \& Environment” 2013, Vol. 5, s. 117-112. Zobacz także: A. Caragliu, Ch. Del Bo, Do Smart Cities Invest in Smarter Policies? Learning from the Past, Planning for the Future, „Social Science Computer Review” 2016, Vol. 34, No. 6, s. 657-672.

${ }_{9}$ W.H. Dutton, J.G. Blumler, K.L. Kraemer, Wired Cities. Shaping the Future of Communications, GK Hall, Boston 1987.

${ }^{10}$ H. Schaffers et al., Smart Cities and the Future Internet. Towards Cooperation Frameworks for Open Innovation [w:] The Future Internet. Future Internet Assembly 2011. Achievements and Technological Promises, eds. J. Domingue et al., Springer, Heidelberg 2011, s. 434.

${ }^{11}$ Ibidem.

12 J.R. Gil-Garcia, Towards a Smart State? Inter-agency Collaboration, Information Integration, and Beyond, „Information Polity” 2012, Vol. 17, No. 3-4, s. 269-280. Zobacz także: T. Bakıcı, E. Almirall, J. Wareham, A Smart City Initiative: The Case of Barcelona, „Journal of the Knowledge Economy" 2012, Vol. 2, No. 1, s. 1-14.

${ }_{13}$ D. Washburn et al., Helping CIOs Understand "Smart City" Initiatives: Defining the Smart City, Its Drivers, and the Role of the CIO, Forrester Research, Cambridge 2010. 
zauważa ogromną rolę małych i dużych podmiotóu z branży IT w tworzeniu smart city, które są dostawcami gotowych rozwiązań miejskich - innowacyjnych urządzeń i oprogramowań ${ }^{14}$. Wspomniani badacze uskazują na kluczową rolę integracji i koordynacji technologii, które cechują się synergią i powinny być połączone, czego skutkiem będzie poprawa jakości życia i usług u mieście ${ }^{15}$. Jennifer Gabrys zauważa, że w wielu wdrażanych wariantach koncepcji smart city zadaniem technologii cyfrowych jest synchronizacja infrastruktur miejskich w celu polepszenia uydajności zasobów miejskich, dystrybucji usług i partycypacji ${ }^{16}$. Dimitri Schuurman uraz z innymi badaczami twierdzi, że u smart city rozwiązania ICT pozwalają na zbieranie zróżnicowanych danych i informacji związanych z zarządzaniem publicznym, dzięki czemu władze miejskie mogą działać predykcyjnie, reagować i rozwiązywać dane problemy w obszarze miejskim ${ }^{17}$. Z kolei Rob Kitchin za smart city uważa miasto, które cechuje się rozwiniętą komputeryzacją, a urządzenia cyfrowe są wbudowane w przestrzeń miejską, co umożliwia połączenie wielu elementów w mieście ${ }^{18}$.

\section{Media w smart city}

Nowe media u mieście mogą być rozpatrywane jako cele i narzędzia do realizacji koncepcji smart city. Dzięki takim właściwościom jak integracja, interaktywoność i kod binarny ${ }^{19}$, nowe media umożliwiają tworzenie innowacyjnych rozwiązań, które wpływają na sfery społeczną i technologiczną ${ }^{20}$. W procesie tworzenia i korzystania z nowych mediów ważną rolę odgrywają różne urządzenia ze względu na ścisłe powiązanie współczesnych mediów z techniką - poustają one przy uspółdziałaniu człowieka z maszyną ${ }^{21}$. Media u smart city umożliwiają łatuy i otwarty dostęp do zróżnicowanych danych, które nie tracą na swojej jakości w procesie ich kopiowania, przez co każda osoba korzystająca z nowych mediów może uczestniczyć w różnych interakcjach z obiektem medialnym ${ }^{22}$. Nowe media w przestrzeni miejskiej wytwarzają

${ }_{14}$ M. Batty et al., Smart Cities of the Future, „The European Physical Journal Special Topics” 2012, Vol. 214, No. 1, s. 481-518.

${ }^{15}$ Ibidem.

${ }^{16}$ J. Gabrys, Programming Environments. Environmentality and Citizen Sensing in the Smart City, „Environment and Planning D. Society and Space” 2014, Vol. 32, No. 1, s. 30-48.

17 D. Schuurman et al., Smart Ideas for Smart Cities. Investigating Crowdsourcing for Generating and Selecting Ideas for ICT Innovation in a City Context, „Journal of Theoretical and Applied Electronic Commerce Research” 2012, Vol. 7, No. 3, s. 49-62.

18 R. Kitchin, The Real-time City? Big Data and Smart Urbanism, „GeoJournal” 2014, Vol. 79, No. 1, s. 1-14.

${ }_{19}$ J. van Dijk, Społeczne aspekty nowych mediów. Analiza społeczeństwa sieci, przeł. J. Konieczny, Wydawnictwo Naukowe PWN, Warszawa 2010.

${ }^{20}$ M. Lister et al., Nowe media. Wprowadzenie, przeł. M. Lorek, A. Sadza, K. Sawicka, Wydaunictwo Uniwersytetu Jagiellońskiego, Kraków 2009.

${ }^{21}$ Nowe media $w$ komunikacji społecznej $w$ XX wieku. Antologia, projekt i red. M. Hopfinger, Oficyna Naukowa, Warszawa 2002.

${ }^{22}$ L. Manovich, Język nowych mediów, Wydawnictua Akademickie i Profesjonalne, Warszawa 2006. 
między innymi nowe sposoby komunikacji i odbioru przekazu, nowe rodzaje form gatunkowych, rozrywki, wzorców konsumpcji, nowe sposoby reprezentacji świata u sferze cyfrowej czy też nowe doświadczenia u relacji między cielesnością, tożsamością i społecznością, na przykład poprzez doświadczenie czasu, miejsca i przestrzeni ${ }^{23}$.

Media u smart city przyczyniają się rozpouszechniania się procesów komunikacyjnych w mieście drogą cyfrową, tworząc w ten sposób ekosystem interpołączonych elementów. Celem smart city staje się wytuorzenie platformy miejskiej w sferze cyfrowej, w której media i technologie łączą władze lokalne, mieszkańców i inne podmioty odpowiedzialne za dobro publiczne ${ }^{24}$. Traktowanie smart city jako cyfrowej platformy komunikacyjnej sprzyja szybkiej i przejrzystej wymianie informacji, kolekcjonowaniu danych, zarządzaniu miastem, partycypacji obywatelskiej, zabieganiu zagrożeniom czy też przyciągnięciu inwestorów. W tym celu należy wytworzyć odpowiednią infrastrukturę, która umożliwi połączenie między fizyczną a cyfrową sferą miasta ${ }^{25}$. Platforma powinna umożliwiać wielostronną komunikację i przestrzeń interakcyjną poprzez partycypacyjną i otwartą infrastrukturę.

Kiedy analizujemy infrastrukturę mediów u mieście można wyodrębnić dwa jej typy: fizyczny (np. drogi, budynki) i cyfrowy (media i ICT) ${ }^{26}$. Część infrastruktury mediów u smart city jest namacalna i widoczna, na przykład komputery i smartfony, a część pozostaje niewidoczna (np. oprogramowania i algorytmy) ${ }^{27}$. Posiłkując się tym rozróżnieniem, Samir Bhowmik proponuje mówienie o dwóch typach infrastruktury mediów - twardej (hardware) i miękkiej (software)28. Przy czym należy podkreślić, że podział ten nie jest ścisły, ponieważ części infrastruktury twardej i miękkiej wzajemnie się przenikają i uspółpracują, tworząc uspólnie konkretne rozwiązanie u przestrzeni miejskiej, na przykład aplikację mobilną na smartfon. Właściwie zbudowana infrastruktura mediów w smart city pozwala zrozumieć i monitorouać zdarzenia u mieście, które z kolei umożliwiają uzyskanie i udostępnianie informacji w sferze publicznej.

\section{Metodologia}

Badanie roli mediów u smart city Warszawa zostało oparte na metodzie studium przypadku (case study). Celem artykułu jest sprawdzenie uykorzystania potencjału mediów u przestrzeni miejskiej w obliczu pandemii COVID-19 na przykładzie uspomnianego ucześniej miasta. Badanie jest oparte na analizie strategii smart city i instytucji zaangażowanych $w$ ich realizację $w$ kontekście praktycznej implementacji

\footnotetext{
${ }^{23}$ M. Lister et al., Nowe media...

${ }^{24}$ S. Toporkoff, H. Rannou, The City as a Platform [w:] Smarter Cities for a Bright Sustainable Future. A Global Perspective, eds. A.R. Shark, S. Toporkoff, S. Levy, Public Technology Institute, Washington 2014.

${ }_{25}$ S. Mattern, http://wordsinspace.net (dostęp: 13.09.2020).

${ }^{26}$ A. Haidine et al., The Role of Communication...

${ }_{27}$ S. Bhowmik, Deep Time of the Museum. The Materiality of Media Infrastructures, Aalto University, Helsinki 2016.

${ }^{28}$ Ibidem.
} 
nouych mediów w tkankę miasta przez władze miejskie. W tym celu dokonano analizy literatury przedmiotu, dokumentów strategicznych, broszur oraz stron internetowych.

Ze względu na wieloznaczność pojęcia smart city i różne podejścia badawcze, autor przyjmuje definicję smart city, według której jest to miasto uykorzystujące technologie informacyjne i komunikacyjne oraz innowacyjne narzędzia w celu optymalizacji życia mieszkańców i zarządzania miastem. Autor dokonuje analizy tak zwanych nowych mediów, które poustały na bazie technologii informacyjnych i komunikacyjnych, zuracając uwagę zarówno na kanał (infrastruktura miękka), jak i środek przekazu (infrastruktura twarda). Mediami w smart city są platformy ICT, oprogramowania, aplikacje mobilne, virtual reality, media online i społecznościoue, jak róunież smartfony, cyfrowe ekrany miejskie, sensory, smart siatki (grids) itp. Głównymi pytaniami badauczymi, sprawdzanymi w tym artykule, są: Czy pandemia COVID-19 spowodowała zmiany u realizowanej strategii smart city w Warszawie? Czy i dla jakich celów są wykorzystywane media w przestrzeni miejskiej w czasie pandemii?

Do przeprowadzenia studium przypadku została uybrana stolica Polski - Warszawa. Wspomniane miasto od kilku lat podejmuje zdecydowane kroki w kierunku rozwijania strategii smart city. Warszawa jest stolicą Polski oraz województwa mazowieckiego i pełni kluczową rolę $w$ aspektach administracyjnym, politycznym, społecznym, gospodarczym, edukacyjnym i kulturouym. Warszawa jest często uważana za najbardziej smart miasto u Polsce, o czym świadczy jej obecność i najwyższe miejsca, w porównaniu do innych polskich miast, $\mathrm{w}$ światowych rankingach dotyczących miast, na przykład Smart City Index ${ }^{29}$ czy The World's Best Cities ${ }^{30}$.

Hipotezą badawczą jest stuierdzenie, że władze miejskie Warszawy, dostosourując strategię smart city w czasie pandemii, rozwijają usługi miejskie na podstawie budowania platformy komunikacyjnej. Przesłanką do wysunięcia tej hipotezy są widoczne działania władz miejskich Warszawy w kierunku stworzenia jednego wielofunkcyjnego centrum kontaktu dla mieszkańców w postaci platformy internetowej. Specyfika platformy internetowej umożliwia dodawanie oraz usuwanie urządzeń lub kanałów komunikacyjnych bez naruszenia funkcjonalności jej działania. Cyfrowy charakter platformy pozwala mieszkańcom na korzystanie z niej u niemal każdym miejscu i czasie oraz umożliwia im personalizację i indywidualizację u procesie komunikacji online. Dodatkowo platforma internetowa uydaje się kluczouym medium w czasie pandemii, ze uzględu na coraz silniejszą konwergencję mediów w różnych urządzeniach, takich jak smartfon czy laptop oraz przyjazny, szybki i łatuy interfejs poszczególnych narzędzi komunikacji cyfrowej.

\footnotetext{
${ }^{29}$ Smart City Index, https://wuw.imd.org/smart-city-observatory/smart-city-index/ (dostęp: 10.01.2021).

${ }^{30}$ Best Cities, https://wuw.bestcities.org/rankings/worlds-best-cities/ (dostęp: 10.01.2021).
} 


\section{Strategia smart city Warszawa}

Miasto stołeczne Warszawa nie posiada oficjalnego dokumentu dedykowanego bezpośrednio realizacji koncepcji smart city. Władze miejskie Warszawy stworzyły jednak dokument pt. Warszawa Smart City - 7 opowieści o inteligentnym rozwoju miasta, promujący omawianą koncepcję ${ }^{31}$. W dokumencie tym określono siedem głównych obszarów działania, które mają uczynić stolicę Polski smart city: zrównoważona mobilność, zdrowe środowisko, innowacyjna gospodarka, zaangażowani mieszkańcy, wysoka jakość życia, efektywne zarządzanie oraz ,ja” w inteligentnym mieście. W omawianym dokumencie podkreślono rolę między innymi smart urządzeń w gospodarstwach domouych w celu obniżenia zużycia energii, inwestycji w innowacyjną i kreatywną gospodarkę, zapeunienia bezpieczeństua i wygody mieszkańcom oraz efektyunego zarządzania stolicą poprzez nowe technologie.

Za realizację koncepcji smart city w Warszawie odpowiadają poszczególne jednostki należące do struktury Urzędu m.st. Warszauy, przede uszystkim Miejskie Centrum Sieci i Danych oraz Biuro Cyfryzacji Miasta, u którym powołano zespół do realizacji projektów dedykowanych smart city. Zaróuno jedna, jak i druga komórka w swoich działaniach dąży do rozwoju innowacji i infrastruktury oraz usług cyfrowych. Ważnym kierunkiem działań strategicznych jest stworzenie zintegrowanej platformy miejskiej, będącej kanałem komunikacji, źródłem danych oraz pozwalającej na skorzystanie z e-usług i rozwiązań Internetu Rzeczy ${ }^{32}$. Dostęp do platformy ma być prosty i otwarty oraz umożliwiać całodobową komunikację dla mieszkańców z odmiennymi oczekiwaniami i różnym poziomem kompetencji cyfrowych. Zadaniem platformy jest róunież integracja innych platform $w$ jednym miejscu. Podstawouym obszarem do dalszego rozwijania platformy ma być istniejąca już platforma - Warszawa 19115, która już teraz jest wielokanałowym centrum kontaktu miejskiego ${ }^{33}$. Władze miejskie dążą także do stuorzenia platformy zapeuniającej szeroki zakres e-usług, dzięki czemu za pomocą jednego dostępu, na przykład logowania, możliue będzie skorzystanie z wielu usług miejskich drogą cyfrowąa ${ }^{34}$. Platforma danych (API) ma umożliwić dostęp do jasnych i czytelnych danych z przestrzeni miejskiej, co ma upłynąć na przejrzystość działań i zwiększyć aktyuny udział mieszkańców u życiu stolicy ${ }^{35}$. Natomiast platforma Internetu Rzeczy (Internet of Things, IoT) ma za zadanie upłynąć pozytyunie na rozwój miejskiej gospodarki innowacyjności i kreatywności, poprzez dostarczanie danych kolekcjonowanych dzięki siatce sensorycznej udrożonej w tkankę miejskąa.

\footnotetext{
31 Warszawa Smart City - 7 opowieści o inteligentnym rozwoju miasta, https://cyfrowabiblioteka.um.warszawa.pl/files/original/0a9aa990c42965b018781192a22c8b15.pdf (dostęp: 10.01.2021). 32 T. Demiańczuk, Rozwiązania smart city musza być zintegrowane, http://wuw.um.warszawa. pl/en/ aktualnosci/rozwi-zania-smart-city-musz-zintegrowane (dostęp: 20.01.2021).

${ }^{33}$ Warszawa 19115, https://warszawa19115.pl/ (dostęp: 20.01.2021).

${ }^{34}$ T. Demiańczuk, Rozwiazania smart city...

${ }_{35}$ Otwarte dane - czyli dane po warszawsku, https://api.um.warszawa.pl/ (dostęp: 20.02.2018).

${ }^{36}$ T. Demiańczuk, Rozwiązania smart city...
} 
Głównym dokumentem strategicznym określającym ogólne cele i założenia związane z rozwojem stolicy Polski jest strategia miejska pt. \#Warszawa2030 ${ }^{37}$. W oficjalnym dokumencie strategicznym nakreślono obszary i kierunki działań do 2030 roku, dzięki którym Warszawa stanie się miastem przyszłości. W dokumencie głóuny nacisk jest kładziony na mieszkańca, który ma być aktyunie zaangażowany u tworzenie i funkcjonowanie miasta. W dokumencie określono trzy głóune uymiary strategii: aktyuni mieszkańcy, przyjazne miejsce i otwarta metropolia. W każdym wymiarze określono bardziej szczegółowo obszary, a następnie wyzwania dla każdego z nich (tabela 1).

Tabela 1. Najważniejsze wymiary strategii \#Warszawa2030

\begin{tabular}{|c|c|c|}
\hline Wymiar & Obszar & Wyzuania \\
\hline \multirow{4}{*}{$\begin{array}{l}\text { Aktyuni mieszkańcy } \\
\text { Przyjazne miejsce } \\
\text { Otwarta metropolia }\end{array}$} & $\begin{array}{l}\text { Odpouviedzialna uspólnota } \\
\text { mieszkańców }\end{array}$ & $\begin{array}{l}\text { - Dbanie o siebie nauzajem } \\
\text { - Decydouanie o przyszłości i strategii miasta }\end{array}$ \\
\hline & Wygodna lokalność & $\begin{array}{l}\text { - Dostęp do mieszkań } \\
\text { - Aktyune spędzanie czasu uolnego } \\
\text { - Tworzenie warunkóu dla rozwoju } \\
\text { przedsiębiorczości }\end{array}$ \\
\hline & \begin{tabular}{|l|} 
Funkcjonalna przestrzeń \\
\end{tabular} & $\begin{array}{l}\text { - Korzystanie z atrakcyjnej przestrzeni publicznej } \\
\text { - Życie w czystym środowisku naturalnym } \\
\text { - Korzystanie z przyjaznego systemu transportu } \\
\text { miejskiego }\end{array}$ \\
\hline & Twórcze środowisko & $\begin{array}{l}\text { - Rozuijanie tuórczego potencjału mieszkańcóu } \\
\text { - Wspieranie talentóu i lideróu } \\
\text { - Inspirouanie śuiata }\end{array}$ \\
\hline
\end{tabular}

Źródło: \#Warszawa2030. Strategia, http://2030.um.warszawa.pl/wp-content/uploads/2018/04/ Strategia-Warszawa2030.pdf (dostęp: 11.01.2021).

Za realizację strategii odpowiada Urząd m.st. Warszawy, a jej nadzór jest prowadzony przez Prezydenta Warszawy, który uskazuje biuro do monitorowania implementacji strategii rozwojowej stolicy. Wspominane biuro ma za zadanie czuwać nad spójnością realizowanych projektów i działań, które powinny pokrywać się z wyznaczonymi celami strategicznymi. W dokumencie \#Warszawa2030 nie zostały jednak wymienione nazwy komórek lub departamentów odpowiedzialnych za realizację poszczególnych zadań i celów ${ }^{38}$. W oficjalnym dokumencie strategicznym nie wyszczególniono bezpośrednio roli nowych technologii, ale ich znaczenie można dostrzec w wyznaczonych wyzwaniach rozwoju Warszawy. Cele strategii rozwoju miasta są realizowane poprzez zróżnicowane programy i projekty, jednak dokument nie zawiera informacji o ich nazwach i formie planowanych projektów. Tym samym władze miejskie pozostawiają dużą elastyczność wyboru implementacji narzędzi i środków oraz ich charakteru w przestrzeni miejskiej. Takie działanie umożliwia testowanie różnych narzędzi, a w przypadku sukcesu ich truałe udrożenie oraz dostosowywanie się do dynamicznie zmieniającego się otoczenia

37 Warszawa 2030, http://2030.um.warszawa.pl/up-content/uploads/2018/04/Strategia-Warszawa2030.pdf (dostęp: 11.01.2021).

${ }^{38}$ Ibidem. 
społeczno-technologicznego, bez konieczności uywiązywania się z jasnych i ściśle określonych zdań.

Innym dokumentem, w którym można odnaleźć odniesienia do realizacji koncepcji smart city w Warszawie, jest Polityka Cyfrowej Transformacji m.st. Warszawy ${ }^{39}$. Jest on powiązany z główną strategią \#Warszawa2030 i ma być realizowany zgodnie z przyjętymi w oficjalnej strategii celami strategicznymi (rys. 1).

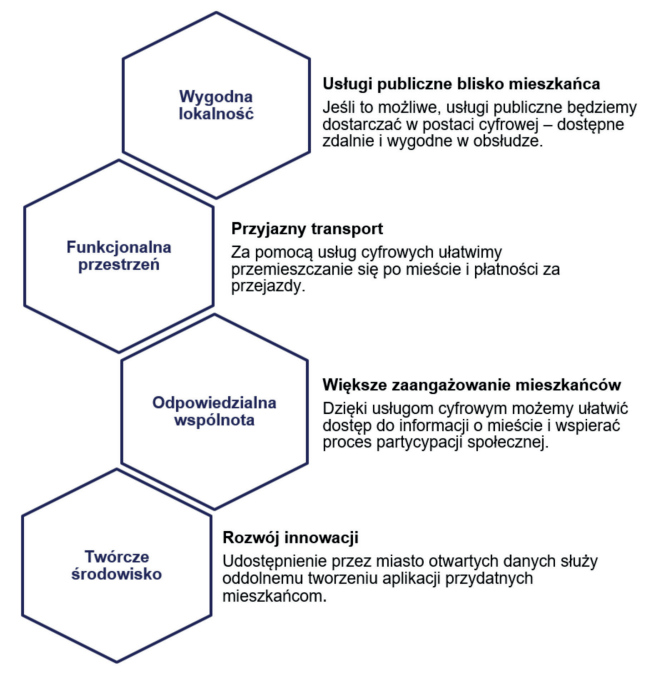

Rysunek 1. Przykłady powiązań transformacji cyfrowej z celami strategicznymi zawartymi w strategii \#Warszawa2030

Źródło: Polityka Cyfrowej Transformacji m.st. Warszawy, http://2030.um.warszawa.pl/ cyfrowa-transformacja/ (dostęp: 20.04.2021).

Dokument został przyjęty przez władze warszawskie w lutym 2021 roku i określa, w jakim kierunku ma rozwijać się cyfrowo miasto do 2030 roku. Opisano w nim koncepcję rozwoju Warszawy w dziedzinie nowych technologii i cyfryzacji. Ponadto uskazano wartości, którym rozwój stolicy jest podporządkowany oraz wyznaczono zasady działania instytucji miasta. W Polityce Cyfrowej... wyjaśniono wiele pojęć technologicznych, w tym smart city, Internet Rzeczy, e-usługi czy użytkounika miasta, które mają przybliżyć mieszkańcom ich znaczenie. Przyszłościowa transformacja cyfrowa miasta ma być związana z postępującą automatyzacją usług publicznych i procesów wewnętrznych oraz cyfryzacją zasobów, co upłynie pozytywnie na prostsze, bardziej oszczędne i efektywne sposoby działania instytucji miejskich. Głównymi elementami transformacji cyfrowej Warszauy powinny być dane, usługi i procesy, technologie oraz ludzie, którzy są najważniejszym zasobem miasta (rys. 2).

${ }^{39}$ Polityka Cyfrowej Transformacji m.st. Warszawy, http://2030.um.warszawa.pl/cyfrowa-transformacja/ (dostęp: 20.04.2021). 


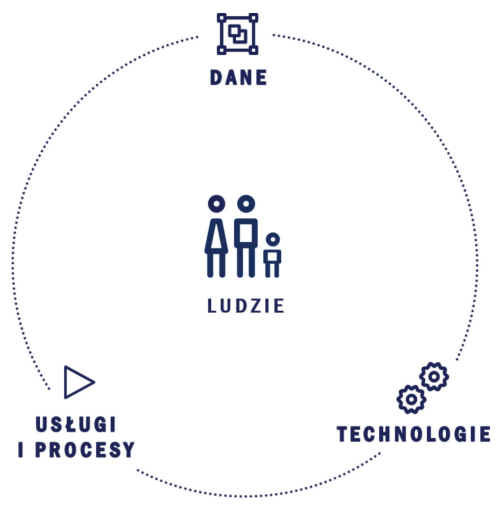

Rysunek 2. Elementy cyfrowej transformacje m.st. Warszawy.

Źródło: Polityka Cyfrowej Transformacji m.st. Warszawy, http://2030.um.warszawa.pl/ cyfrowa-transformacja/ (dostęp: 20.04.2021).

Dokument zakłada zastosowanie szeregu technologii cyfrowych w wielu obszarach działania miasta u celu podnoszenia jakości życia mieszkańców stolicy. Do realizacji tego zadania wyznaczono takie technologie i rozwiązania, jak sztuczna inteligencja, przetwarzanie wielkich zbiorów danych (big data), otwieranie danych miejskich, Internet Rzeczy, rozproszone rejestry transakcji (typu blockchain), projektowanie architektury informacyjnej czy standardu sieci komórkowej $5 \mathrm{G}^{40}$.

\section{Media w smart city Warszawa}

Podstawouym punktem informacji dla warszawiaków w przestrzeni cyfrowej są oficjalne strony i podstrony internetowe Urzędu, tworzone w domenie um.warszawa.pl ${ }^{41}$. Obywatel Warszawy znajdzie tam wiele informacji dotyczących między innymi bieżących zdarzeń mieście, życia mieszkańca, spraw urzędowych, czy prowadzenia działalności gospodarczej u stolicy Polski. Przykładowo na podstronie poświęconej kulturze i sztuce - Kulturalna Warszawa - użytkownik może uzyskać informacje na temat instytucji kultury i sztuki w Warszawie, konkursów i stypendiów dla artystów oraz kalendarza wydarzeń kulturalnych, w tym także ich emisji online ${ }^{42}$. Innym źródłem informacji i kanałem komunikacyjnym dla mieszkańców Warszawy są strony Urzędu w mediach społecznościowych. Władze warszauskie są obecne na takich mediach

\footnotetext{
${ }^{40}$ Ibidem.

${ }^{41}$ Urzą m.st. Warszawy, http://wuw.um.warszawa.pl (dostęp: 20.04.2021).

${ }^{42}$ Kulturalna Warszawa, http://kulturalna.warszawa.pl (dostęp: 20.04.2021).
} 
społecznościouych, jak Twitter ${ }^{43}$, Facebook ${ }^{44}$, Instagram ${ }^{45}$ i YouTube ${ }^{46}$. Poszczególne Biura Urzędu również posiadają oddzielne konta na mediach społecznościouych, czego przykładem może być profil na Facebooku wcześniej uspomnianej Kulturalnej Warszawy $^{47}$.

Największe wysiłki w realizacji koncepcji smart city u obszarze mediów w Warszawie można dostrzec w rozwijaniu platformy komunikacyjnej - Warszawa $19115^{48}$. Jest to wielokanałowe centrum kontaktu, do którego można uzyskać dostęp poprzez linię telefoniczną, SMS-y, witrynę internetową oraz aplikację mobilną. Z platformy można skorzystać za pomocą smartfonu, komputera, tabletu czy telefonu stacjonarnego. Warszawa 19115 umożliwia mieszkańcom Warszauy bezpłatny dostęp do informacji na temat funkcjonowania miasta, urzędów i poszczególnych komórek miejskich czy zdarzeń i zmian u stolicy Polski. Platforma pozwala na zgłaszanie awarii i usterek oraz dzielenie się pomysłami związanymi z obszarem stołecznym. Umożliwia ona uzyskiwanie informacji i otrzymywanie powiadomień dotyczących zdarzeń w Warszawie. Na platformie można róunież znaleźć informacje o projektach i programach lokalnych, takich jak Inicjatywa lokalna, która jest formą uspółpracy samorządu z obywatelami na rzecz społeczności lokalnej ${ }^{49}$.

Jednym z kluczouych projektów smart city podjętych przez Urząd m.st. Warszawy jest tworzenie platformy otwartych danych miejskich - Otwarte dane po warszawsk ${ }^{50}$. Na platformie są umieszczane dane o funkcjonowaniu miasta, zarówno w trybie offline, jak i online, które są gromadzone i udostępniane w jednolity sposób. Celem projektu jest podniesienie jakości życia mieszkańców poprzez udostępnianie uporządkowanych i przydatnych informacji. Otwarte dane miejskie mają stanowić inspirację i usparcie dla mieszkańców, organizacji i podmiotów prywatnych, którzy na ich bazie chcą budować oprogramowania i aplikacje w przestrzeni miejskiej. Na platformie można znaleźć dane miejskie na temat między innymi kultury, edukacji, transportu miejskiego, ekologii czy nieruchomości. Otwarty i łatuy dostęp do danych o funkcjonowaniu miasta ma zbliżyć obywateli do korzystania z usług cyfrowych i pomóc zrozumieć procesy miejskie zachodzące w Warszawie.

\footnotetext{
43 Tuitter, Oficjalny profil miasta stolecznego Warszawy, https://tuitter.com/warszawa (dostęp: 20.04.2021).

${ }^{44}$ Facebook, Miasto stołeczne Warszawa, https://www.facebook.com/warszawa (dostęp: 20.04.2021).

45 Instagram, Miasto stoleczne Warszawa, https://www.instagram.com/miasto_warszawa/ (dostęp: 20.04.2021).

${ }_{46}$ YouTube, Warszawa, https://www.youtube.com/channel/UCJu5HBjC07UZG6AKpIfsr7Q (dostęp: 20.04.2021).

${ }^{47}$ Facebook, Kulturalna Warszawa, https://wwu.facebook.com/KulturalnaWarszawa (dostęp: 20.04.2021).

${ }^{48}$ Warszawa 19115...

${ }^{49}$ Inicjatywa lokalna, https://warszawa19115.pl/-/inicjatywa-lokalna (dostęp: 20.04.2021).

${ }^{50}$ Otwarte dane - czyli dane po warszawsku...
} 
Innym ciekawym projektem władz warszawskich było utworzenie platformy internetowej Otwarta Warszawa, opartej na danych miejskich ${ }^{51}$. Rozwiązanie miało na celu włączenie mieszkańców u proces uspólnego tworzenia Warszawy na zasadzie crowdsourcingu, czyli poprzez pozyskiwanie informacji i realizację zadań przez otwarte uczestnictuo mieszkańców. Na platformie warszawiacy mogli proponować suoje pomysły dotyczące rozwoju miasta, głosować na najlepsze z nich i brać udział w konkursach. W ciągu dwóch lat (2014-2015) zgłoszono 1147 pomysłów, z których następnie jury wybrało kilka idei do wdrożenia w przyszłości. Przykładem realizacji jednego z pomysłów była inicjatywa I Love Warsaw, która polegała na zaproponowaniu przez mieszkańców autorskich i alternatywnych tras turystycznych po Warszawie oraz realizacji spotu z ich udziałem, promującego wyznaczone szlaki ${ }^{52}$. Co ciekawe, pod adresem otwartawarszawa.pl, na którym wcześniej funkcjonowała uspomniana platforma partycypacyjna, obecnie można znaleźć portal informacyjny z artykułami na temat atrakcji czy z pomysłami na spędzanie czasu wolnego w czasie pandemii w stolicy Polski ${ }^{33}$.

W latach 2014-2015 zorganizowano konkurs Dane po warszawsku, którego ideą było stworzenie aplikacji ułatwiających życie $w$ Warszawie poprzez wykorzystanie otwartych danych publicznych. Organizatorami konkursu byli Urząd m. st. Warszawy, Politechnika Warszauska, Orange Labs oraz Fundacja TechSoup. Twórcy zuycięskich projektów otrzymali usparcie, które pozwoliło na dalsze rozwinięcie pomysłu. W konkursie zuyciężyła aplikacja Warszawski ninja, umożliwiająca zgłaszanie uszelkich utrudnień w podróżowaniu transportem miejskim oraz proponująca inną optymalną trasę komunikacji w czasie utrudnienia ${ }^{54}$. W konkursie wyróżniono również aplikację Bezpieczna Warszawa, która dzięki otwartym danym pozwala zgłosić i poinformować innych mieszkańców o sytuacji zagrożenia, takiej jak napaść, wypadek, zasłabnięcie czy też zdarzenie losoue $\mathrm{e}^{55}$.

Oprócz personalnych środków przekazu używanych przez mieszkańców Warszawy, takich jak smartfon, tablet czy komputer, ważnymi częściami infrastruktury twardej mediów są cyfrowe ekrany miejskie. W stolicy Polski w transporcie miejskim jest umieszczonych blisko 6500 ekranów cyfrouych, przy czym w autobusach i tramwajach miejskich liczba ekranów wynosi $4382^{56}$, natomiast w metrze około $2000^{57}$. Ekrany w przestrzeni miejskiej spełniają ważną funkcję nie tylko informacyjną na temat zdarzeń w stolicy, lecz także rozrywkową, edukacyjną, reklamową i kulturową. Warto dodać,

\footnotetext{
${ }^{51}$ I Love Warsaw!, http://otwartawarszawa.pl/ilovewarsaw/ (dostęp:17.06.2017).

${ }^{52}$ Spoty I love Warsaw, https://warszawa.naszemiasto.pl/tag/spoty-i-love-warsaw (dostęp: 10.01.2021).

${ }^{53}$ Otwarta Warszawa - o stolicy, https://otwartawarszawa.pl (dostęp: 10.01.2021).

${ }^{54}$ Aplikacja Warszawski ninja, https://warszawa.naszemiasto.pl/tag/aplikacja-warszauski-ninja (dostęp: 10.01.2021).

${ }^{55}$ Bezpieczna Warszawa, http://ravineteam.com/bu.html (dostęp: 10.01.2021).

${ }^{56}$ Reklama w komunikacji miejskiej $w$ Warszawie, https://lokalmedia.pl/komunikacja-miejska-warszawa/ (dostęp: 20.04.2021).

57 Stroer TV, https://www.stroeer.pl/nosniki/stroer-tv (dostęp: 20.04.2021).
} 
że organizacje pozarządowe mają możliwość bezpłatnej emisji spotów na ekranach w warszauskiej komunikacji miejskiej ${ }^{58}$. Mieszkańcy Warszawy mają róunież dostęp do bezpłatnej sieci bezprzewodowej Urzędu m. st. Warszauy - hotspot UM-Warszawa. Na stronie internetowej dedykowanej sieci hotspot UM-Warszawa obywatele stolicy mogą sprawdzić za pomocą mapy lub listy dostępne punkty bezprzewodowej sieci miejskiej u poszczególnych częściach miasta ${ }^{59}$.

\section{Strategia smart city Warszawa a COVID-19: wykorzystanie nowych mediów}

W czasie pandemii media powinny ułatuiać procesy komunikacyjne oraz informować mieszkańcóu miast o dynamicznie zmieniającej się sytuacji spowodowanej pandemią COVID-19, dlatego władze miejskie Warszawy podjęły działania mające na celu wykorzystanie potencjału nowych mediów w przestrzeni miejskiej.

W dobie pandemii we wdrażaniu koncepcji smart city w Warszawie ważną rolę spełnia ucześniej uspomniana platforma Warszawa 19115, która dzięki swojej specyfice umożliwiła rozbudowanie i wykorzystanie istniejącego kanału komunikacji cyfrowej. Na platformie, oprócz zakładek poświęconych, między innymi zarządzaniu odpadami komunalnymi czy możliwości rezerwacji wizyt w poszczególnych urzędach miejskich, została utuorzona sekcja poświęcona koronawirusowi ${ }^{60}$. Zakładka ta posiada aż kilka wersji językowych: polską, angielską, ukraińską i rosyjską. Użytkounik znajdzie tam osiem podsekcji, podzielonych na obszary działania wraz z ich szczegółowym opisem i uskazówkami:

- Szczepienia, zalecenia - informacje dotyczące szczepień przeciwko koronawirusowi; miejsca, terminy i kolejność szczepień; zalecenia dla mieszkańców;

- Najnousze informacje - aktualne informacje dotyczące funkcjonowania Warszawy u czasie pandemii oraz wiadomości o bieżących zmianach u mieście;

- Sprawy urzędowe - informacje o charakterze spraw możliuych do realizacji przez internet lub osobiście; godziny funkcjonowania poszczególnych urzędów w czasie pandemii;

- Przedsiębiorcy, organizacje społeczne - działania, które podejmuje Warszawa u celu usparcia przedsiębiorców i organizacji pozarządowych;

- Opieka zdrowotna, szpitale - informacja o placówkach z oddziałami zakaźnymi; działania Warszawy u kierunku zapewnienia opieki zdrowotnej dla wszystkich mieszkańców;

- Transport publiczny - funkcjonowanie transportu publicznego u czasie pandemii oraz podejmowane środki ochrony i bezpieczeństwa w pojazdach miejskich;

\footnotetext{
${ }^{58}$ Spoty promocyjne w komunikacji miejskiej, https://ngo.um.warszawa.pl/promocja-dzia-a-ngo/ spoty-promocyjne-w-komunikacji-miejskiej (dostęp: 20.04.2021).

${ }^{59}$ Hotspot UM-Warszawa, https://hotspot.um.warszawa.pl (dostęp: 20.04.2021).

${ }^{60}$ Warszawa 19115 - koronawirus, https://warszawa19115.pl/koronawirus (dostęp: 20.04.2021).
} 
- Edukacja, kultura i sport - informacja o czasowo zamkniętych placówkach miejskich; informacje dla rodziców i uczniów o szkołach, przedszkolach i żłobkach; funkcjonowanie kin, teatrów, restauracji, basenów i ośrodków sportu w czasie pandemii;

- Seniorzy. System usparcia - zalecenia dla seniorów zuiązane z zapobieganiem zachorowaniu i powikłania; informacje o punktach pomocy dla seniorów oraz promowanie działalności wolontariackiej.

Za pomocą Warszawa 19115 u 2020 roku warszawiacy wysłali 666058 zgłoszeń, z czego 372261 stanowiły zgłoszenia interwencyjne, a 215893 zgłoszenia informacyjne $^{61}$. W omawianym roku interwencje stanowiły $56 \%$ uszystkich zgłoszeń, z kolei zapytania informacyjne 32,4\%. W marcu 2020 roku, czyli miesiącu ogłoszenia światowej pandemii COVID-19, mieszkańcy Warszawy kontaktowali się 50163 razy, o ponad 4000 więcej niż w tym samym czasie rok wcześniej. Najwięcej zgłoszeń upłynęło we urześniu 2020 roku - 56 852. Okres wiosenny (marzec-kwiecień) oraz jesienny (urzesień-październik) były najbardziej intensywnymi miesiącami pod kątem liczby zgłoszeń wysłanych przez platformę w 2020 roku $^{62}$.

Ze względu na pandemię władze warszawskie zdecydowały się utworzyć nowe witryny internetowe oraz rozbudować istniejące już serwisy informacyjne online, które mają być źródłem informacji i kanałem kontaktu u sferze cyfrowej dla mieszkańców Warszawy.

Warszawa Szczepi to portal informacyjny na temat procesu szczepień przeciu COVID-19 w obszarze Warszawy ${ }^{63}$. Na uspomnianej stronie wuw można znaleźć informacje dotyczące punktów szczepień z ich adresami na terenie Warszawy, procedury kualifikacji i zgłaszania się do szczepień czy aktualnych ofert pracy dla personelu medycznego do zespołów Warszauskich Punktów Szczepień Pouszechnych i Populacyjnych przeciu COVID-19.

W czasie pandemii COVID-19 ważną rolę odgrywa cyfrowy kanał kontaktu, Ochotnicy Warszawscy ${ }^{64}$. Projekt został zainicjowany u 2016 roku, a jego cele to rozwój i promocja wolontariatu w Warszawie. Działania podejmowane w ramach realizacji projektu są skierowane do organizatorów wolontariatu, wolontariuszy i wszystkich osób zainteresowanych tematyką wolontariatu na terenie stolicy Polski. Oprócz ofert wolontariatu oraz informacji o projekcie, szkoleniach i wydarzeniach, a także informacji dla organizatorów i wolontariuszy, na omawianej stronie internetowej została utworzona specjalna sekcja (zakładka) o nazwie Działania COVID-1965. Na omawianej podstronie szczegółowo opisano główne działania w ramach realizacji pomocy wolontariackiej w dobie pandemii, które zostały podzielone na cztery kategorie tematyczne: Zostań

\footnotetext{
${ }_{61}$ Podsumowanie 2020: Miejskie Centrum Kontaktu Warszawa 19115, https://www.um.warszawa.pl/aktualnosci/podsumowanie-2020-miejskie-centrum-kontaktu-warszawa-19115 (dostęp: 20.01.2021).

${ }^{62}$ Ibidem.

${ }^{63}$ Warszawa Szczepi, https://wwu.warszawaszczepi.pl (dostęp: 20.04.2021).

${ }^{64}$ Ochotnicy Warszawscy, https://ochotnicy.waw.pl (dostęp: 18.04.2021).

${ }^{65}$ Działania COVID-19, Ochotnicy Warszauscy, https://ochotnicy.waw.pl/dzialania-COVID-19 (dostęp: 20.04.2021).
} 
darczyńcą, Wsparcie mieszkańców, Pomoc sąsiedzka i inicjatywy warszawiaków oraz Wsparcie medyków. Warto róunież dodać, że na omawianej stronie www zdecydowana większość ofert wolontariatu dotyczy poszukiwania wolontariuszy do Punktów Szczepień Pouszechnych w poszczególnych placówkach w Warszawie.

Pandemia przyczyniła się do rozbudowania treści na oficjalnych stronach internetowych Urzędu w domenie um.warszawa.pl o informacje dotyczące pandemii ${ }^{66}$. Przykładowo mieszkańcy mogą znaleźć tam bieżące wiadomości na temat rejestracji na szczepienie w Warszawie przeciu COVID-19 czy też linki przekierowujące do miejskiego centrum kontaktu Warszawa 19115. W zakładce Rezerwacja wizyt obywatel może dokonać rezerwacji online w poszczególnych komórkach Urzędu m.st. Warszawy czy sprawdzić aktualny stan kolejek ${ }^{67}$. Na podstronie poświęconej edukacji w Warszawie (Biuro Edukacji) są publikowane aktualne informacje dotyczące między innymi organizacji nauczania w czasie pandemii dla nauczycieli, rodziców i uczniów czy dystrybucji maseczek w placówkach szkolnych na terenie miasta stołecznego ${ }^{68}$. Urząd dostrzegł rosnący problem przemocy domowej, który pogłębia się ze względu na izolację społeczną. Dlatego też w ramach inicjatywy Warszawa Antyprzemocowa na stronie internetowej projektu zostały umieszczone szczegółowe informacje i procedura zgłaszania się po pomoc dla ofiar przemocy domowej w czasie pandemii COVID-19 ${ }^{69}$. Z kolei na oficjalnej stronie wuw Zarządu Transportu Miejskiego w Warszawie są publikowane i aktualizowane informacje na temat funkcjonowania transportu miejskiego w czasie pandemii dotyczące na przykład bezpieczeństwa i zasad zachowania w pojazdach publicznych czy uruchomienia specjalnej linii autobusowej (902), dowożącej do punktu szczepień na Stadionie Narodouym ${ }^{70}$. Ciekawą akcją warszawskiego transportu publicznego jest także akcja informacyjna na temat możliwości zawieszenia imiennego biletu komunikacji miejskiej u czasie pandemii i systemu umożliwiającego uykonanie tej procedury online ${ }^{71}$.

Urząd m. st. Warszawy uykorzystuje również dostępne kanały na mediach społecznościouych w celu informowania mieszkańców o bieżących zdarzeniach i zmianach wywołanych pandemią koronawirusa. Posty, zamieszczane na przykład na Facebooku lub Twitterze, informują obywateli o otwarciu nowych punktów szczepień na terenie Warszawy, natomiast na platformie YouTube utworzono specjalną sekcją tematyczną pt. Warszawa walczy z COVID-19, gdzie są publikowane filmy na temat pomocy w czasie pandemii.

${ }_{66}^{66}$ Urzad m.st. Warszawy...

${ }^{67}$ Rezerwacja wizyt, https://rezerwacje.um.warszawa.pl (dostęp: 20.04.2021).

68300 tys. maseczek trafi do szkót i przedszkoli, Biuro Edukacji m.st. Warszawy, https:// edukacja.warszawa.pl/dla-ucznia-i-rodzica/bezpieczenstwo/22536-300-tys-maseczek-trafi-do-szkol-i-przedszkoli (dostęp: 20.04.2021).

69 Warszawa Antyprzemocowa, http://www.um.warszawa.pl/antyprzemocowa/ (dostęp: 22.04.2021).

${ }^{70}$ ZTM: działania w czasie pandemii, Zarząd Transportu Miejskiego w Warszawie, https:// wuw.ztm.waw.pl/informacje-prasowe/2021/04/07/ztm-dzialania-w-czasie-pandemii/ (dostęp: 22.04.2021).

${ }^{71}$ Zawieś WKM, https://zawiesukm.wtp.waw.pl (dostęp: 22.04.2021). 


\section{Podsumowanie i wnioski}

Analiza strategii smart city m.st. Warszauy pozwala stuierdzić, że władze miejskie zauważają potencjał nowych mediów i technologii w budowaniu miasta przyszłości. W ramach realizacji koncepcji smart city w stolicy Polski stosuje się nowe formy mediów, które są zarówno celami, jak i narzędziami jej implementacji. Hipoteza badawcza zakładająca, że władze miejskie Warszawy dostosourują strategię smart city do rzeczywistości pandemicznej i rozwijają usługi miejskie na podstawie budowania platformy komunikacyjnej, została potwierdzona. Zarówno w dokumentach strategicznych, jak i swoich działaniach władze warszawskie wykazały, że realizują zadania ukierunkowane na tworzenie platform internetowych. Natomiast w czasie pandemii wykorzystano funkcjonalność istniejącej platformy Warszawa 19115, rozwijając ją o treści pośuięcone COVID-19.

Realizacja strategii smart city musi odbywać się przy udziale ICT, które są podstawą do tworzenia innowacyjnych rozuiązań i usług cyfrowych. Warszawa nie posiada oficjalnego dokumentu strategicznego dedykowanego smart city, ale realizuje koncepcję poprzez rozproszone projekty w przestrzeni miejskiej. Dokumentem wskazującym ogólne kierunki działania na rzecz tworzenia smart city jest oficjalna strategia miejska \#Warszawa2030, natomiast bardziej szczegółowe zadania i przyszłościowe wykorzystanie technologii określa Polityka Cyfrowej Transformacji m. st. Warszawy. Brak oficjalnego dokumentu strategicznego smart city w Warszawie może być również uważany za działanie strategiczne, ponieważ dzięki temu władze miejskie mogą elastycznie podchodzić do testowania i implementacji poszczególnych smart rozwiązań u mieście, bez konieczności wywiązywania się z konkretnych obietnic spisanych $\mathrm{w}$ formie dokumentu.

W projektowaniu infrastruktury mediów w Warszawie zauważa się nasilone działania u rozwijaniu części miękkich infrastruktury - oprogramowań. W stolicy Polski są rozuijane portale, strony i platformy internetowe, do których mieszkaniec może uzyskać dostęp dzięki urządzeniom mobilnym lub komputerom. Urząd wykazuje wyraźne zainteresowanie rozwiązaniami medialnymi opartymi na platformie komunikacyjnej, czego przykładem jest platforma Otwarte dane po warszawsku czy też Warszawa 19115. Zułaszcza to drugie rozwiązanie jest promowane i rozwijane od wielu lat jako główne centrum kontaktu dla mieszkańców. Strategia smart city Warszawa zakłada tworzenie i wykorzystanie platform internetowych oraz ich integrację, dzięki czemu zostanie zapewniona interoperacyjność komunikacyjna i reprezentacja miasta w sferze cyfrowej. W przyszłości mają zostać utworzone platformy wykorzystujące między innymi Internet Rzeczy i sztuczną inteligencję, które umożliwią pozyskiwanie danych z wielu obszarów funkcjonowania miasta i zautomatyzują procesy komunikacyjne w Warszawie. Inwestycja w środki miękkie infrastruktury mediów pokazuje również budowanie strategii smart city w Warszawie w kierunku wykorzystania danych miejskich, zarówno w celu informowania mieszkańców i zarządzania miastem, jak i pobudzenia gospodarczego ze względu na możliwość tworzenia rozwiązań opartych na danych. Skupiając się na częściach twardych infrastruktury, władze miejskie planują 
wykorzystanie, między innymi sensorów i innych przedmiotów połączonych w ramach Internetu Rzeczy, jednak rozwiązania te są na początkowym etapie rozwoju. Innym elementem infrastruktury twardej, który mógłby być udrożony w tkankę miejską $\mathrm{w}$ Warszawie są smart stations - wielofunkcyjne stacje w obszarze miasta z interaktyunym ekranem z dostępem do internetu, hotspotem, możliwością ładounia urządzeń mobilnych itd., które spełniałyby funkcje informacyjną, edukacyjną i rozrywkową.

Odpowiednio zaprojektowana infrastruktura mediów w mieście umożliwia szybkie wdrożenie nowych kanałów komunikacji. Władze miejskie Warszauy kilka lat przed pandemią rozpoczęły działania mające na celu rozwijanie platformy komunikacyjnej Warszawa 19115, która z założenia miała się stać głóunym punktem informacyjnym i komunikacyjnym dla mieszkańców. W obliczu pandemii wykorzystano jej potencjał i u szybki sposób rozszerzono jej funkcje o treści związane z COVID-19, dzięki czemu w jednym miejscu obywatel ma dostęp do wielu informacji i usług miejskich za pomocą drogi cyfrowej.

\section{Bibliografia}

\section{Monografie}

Bhowmik S., Deep Time of the Museum. The Materiality of Media Infrastructures, Aalto University, Helsinki 2016.

Dutton W.H., Blumler J.G., Kraemer K.L., Wired Cities. Shaping the Future of Communications, GK Hall, Boston 1987.

Miller M., The Internet of Things. How Smart TVs, Smart Cars, Smart Homes, and Smart Cities Are Changing the World, Pearson Education, Indianapolis 2015.

Washburn D. et al., Helping CIOs Under-stand "Smart City" Initiatives: Defining the Smart City, Its Drivers, and the Role of the CIO, Forrester Research, Cambridge 2010.

\section{Monografie tłumaczone}

Dijk J. van, Społeczne aspekty nowych mediów. Analiza społeczeństwa sieci, przeł. J. Konieczny, Wydawnictuo Naukowe PWN, Warszawa 2010.

Lister M. et al., Nowe media. Wprowadzenie, przeł. M. Lorek, A. Sadza, K. Sawicka, Wydawnictuo Uniwersytetu Jagiellońskiego, Kraków 2009.

Manovich L., Język nowych mediów, przeł. M. Patnoń, Wydawnictua Akademickie i Profesjonalne, Warszawa 2006.

Prace pod redakcją

Nowe media $w$ komunikacji spotecznej $w$ XX wieku. Antologia, projekt i red. M. Hopfinger, Oficyna Naukowa, Warszawa 2002.

Smarter as the New Urban Agenda. A Comprehensive View of the 21st Century City, red. J.R. Gil-Garcia, T.A. Pardo, T. Nam, Springer, Heidelberg 2015. 


\section{Rozdziały z książek}

Haidine A., El Hassani S., Aqqal A., El Hannani A., The Role of Communication Technologies in Building Future Smart Cities [w:] Smart Cities Technologies, eds. I. Nunes Da Silva, R. Andrade Flauzino, Intechopen, London 2016.

Schaffers H. et al., Smart Cities and the Future Internet. Towards Cooperation Frameworks for Open Innovation [w:] The Future Internet. Future Internet Assembly 2011. Achievements and Technological Promises, eds. J. Domingue et al., Springer, Heidelberg 2011.

Toporkoff S., Rannou H., The City as a Platform [w:] Smarter Cities for a Bright Sustainable Future. A Global Perspective, eds. A.R. Shark, S. Toporkoff, S. Levy, Public Technology Institute, Washington 2014.

\section{Artykuły z czasopism}

Albino V., Berardi U., Dangelico R.M., Smart Cities: Definitions, Dimensions, Performance, and Initiatives, „Journal of Urban Technology” 2015, Vol. 22, No. 1, s. 3-21.

Bakıcı T., Almirall E., Wareham J., A Smart City Initiative: The Case of Barcelona, „Journal of the Knowledge Economy" 2012, Vol. 2, No. 1, s. 1-14.

Batty M. et al., Smart Cities of the Future, „The European Physical Journal Special Topics” 2012, Vol. 214, No. 1, s. 481-518.

Caragliu A., Del Bo Ch., Do Smart Cities Invest in Smarter Policies? Learning from the Past, Planning for the Future, „Social Science Computer Review” 2016, Vol. 34, No. 6, s. 657-672.

Gabrys J., Programming Environments. Environmentality and Citizen Sensing in the Smart City, „Environment and Planning D. Society and Space” 2014, Vol. 32, No. 1, s. 30-48.

Giffinger R. et al., Smart Cities. Ranking of European medium-sized cities, Vienna University of Technology, Vienna 2007.

Gil-Garcia J.R., Towards a Smart State? Inter-agency Collaboration, Information Integration, and Beyond, „Information Polity” 2012, Vol. 17, No. 3-4, s. 269-280.

Kitchin R., The Real-time City? Big Data and Smart Urbanism, „GeoJournal” 2014, Vol. 79, No. 1, s. 1-14.

Oberti I., Pavesi A.S., The Triumph of the Smart City, „Techne. Journal of Technology for Architecture \& Environment" 2013, Vol. 5, s. 117-112.

O'Grady M., O’Hare G., How Smart Is Your City?, „Science” 2012, Vol. 335, No. 3, s. 1581-1582.

Schuurman D. et al., Smart Ideas for Smart Cities. Investigating Crowdsourcing for Generating and Selecting Ideas for ICT Innovation in a City Context, „Journal of Theoretical and Applied Electronic Commerce Research" 2012, Vol. 7, No. 3, s. 49-62.

\section{Źródła internetowe}

Aplikacja Warszawski ninja, https://warszawa.naszemiasto.pl/tag/aplikacja-warszawski-ninja (dostęp: 10.01.2021).

Best Cities, https://wwu.bestcities.org/rankings/worlds-best-cities/ (dostęp: 10.01.2021).

Bezpieczna Warszawa, http://ravineteam.com/bw.html (dostęp: 10.01.2021).

Demiańczuk T., Rozwiązania smart city musza być zintegrowane, http://www.um.warszawa. pl/en/ aktualnosci/rozwi-zania-smart-city-musz-zintegrowane (dostęp: 20.01.2021).

Działania COVID-19, Ochotnicy Warszauscy, https://ochotnicy.waw.pl/dzialania-COVID-19 (dostęp: 20.04.2021).

Facebook, Kulturalna Warszawa, https://www.facebook.com/KulturalnaWarszawa (dostęp: 20.04.2021). 
Facebook, Miasto stołeczne Warszawa, https://www.facebook.com/warszawa (dostęp: 20.04.2021).

Hotspot UM-Warszawa, https://hotspot.um.warszawa.pl (dostęp: 20.04.2021).

I Love Warsaw!, http://otwartawarszawa.pl/ilovewarsaw/ (dostęp: 17.06.2017).

Inicjatywa lokalna, https://warszawa19115.pl/-/inicjatywa-lokalna (dostęp: 20.04.2021).

Instagram, Miasto stołeczne Warszawa, https://www.instagram.com/miasto_warszawa/ (dostęp: 20.04.2021).

Kulturalna Warszawa, http://kulturalna.warszawa.pl (dostęp: 20.04.2021).

Mattern S., http://wordsinspace.net (dostęp: 13.09.2020).

Ochotnicy Warszawscy, https://ochotnicy.waw.pl (dostęp: 18.04.2021).

Otwarta Warszawa - o stolicy, https://otwartawarszawa.pl (dostęp: 10.01.2021).

Otwarte dane - czyli dane po warszawsku, https://api.um.warszawa.pl/ (dostęp: 20.02.2018).

Podsumowanie 2020: Miejskie Centrum Kontaktu Warszawa 19115, https://www.um.warszawa.pl/aktualnosci/podsumowanie-2020-miejskie-centrum-kontaktu-warszawa-19115 (dostęp: 20.01.2021).

Polityka Cyfrowej Transformacji m.st. Warszawy, http://2030.um.warszawa.pl/cyfrowa-transformacja/ (dostęp: 20.04.2021).

Reklama w komunikacji miejskiej w Warszawie, https://lokalmedia.pl/komunikacja-miejska-warszawa/ (dostęp: 20.04.2021).

Rezerwacja wizyt, https://rezerwacje.um.warszawa.pl (dostęp: 20.04.2021).

Smart City Index, https://www.imd.org/smart-city-observatory/smart-city-index/ (dostęp: 10.01.2021).

Spoty I love Warsaw, https://warszawa.naszemiasto.pl/tag/spoty-i-love-warsaw (dostęp: 10.01.2021).

Spoty promocyjne w komunikacji miejskiej, https://ngo.um.warszawa.pl/promocja-dzia-a-ngo/ spoty-promocyjne-w-komunikacji-miejskiej (dostęp: 20.04.2021).

Stroer TV, https://wuw.stroeer.pl/nosniki/stroer-tv (dostęp: 20.04.2021).

Twitter, Oficjalny profil miasta stotecznego Warszawy, https://twitter.com/warszawa (dostęp: 20.04.2021).

Urząd m. st. Warszawy, http://www.um.warszawa.pl (dostęp: 20.04.2021).

Warszawa Antyprzemocowa, http://www.um.warszawa.pl/antyprzemocowa/ (dostęp: 22.04.2021).

Warszawa Smart City - 7 opowieści o inteligentnym rozwoju miasta, https://cyfrowabiblioteka. um.warszawa.pl/files/original/0a9aa990c42965b018781192a22c8b15.pdf (dostęp: 10.01.2021).

Warszawa Szczepi, https://www.warszawaszczepi.pl (dostęp: 20.04.2021).

Warszawa 19115, https://warszawa19115.pl/ (dostęp: 20.01.2021).

Warszawa 19115 - koronawirus, https://warszawa19115.pl/koronawirus (dostęp: 20.04.2021).

Warszawa 2030, http://2030.um.warszawa.pl/wp-content/uploads/2018/04/Strategia-Warszawa2030.pdf (dostęp: 11.01.2021).

YouTube, Warszawa, https://www.youtube.com/channel/UCJu5HBjC07UZG6AKpIfsr7Q (dostęp: 20.04.2021).

WHO, WHO announces COVID-19 outbreak a pandemic, https:/www.euro.who.int/en/health-topics/health-emergencies/coronavirus-COVID-19/news/news/2020/3/who-announces-COVID-19-outbreak-a-pandemic (dostęp: 8.02.2021).

Zawieś WKM, https://zawieswkm.wtp.waw.pl (dostęp: 22.04.2021). 
ZTM: działania w czasie pandemii, Zarząd Transportu Miejskiego w Warszawie, https:// www.ztm.waw.pl/informacje-prasowe/2021/04/07/ztm-dzialania-w-czasie-pandemii/ (dostęp: 22.04.2021).

$68 \%$ of the world population projected to live in urban areas by 2050, says UN, https://www. un.org/development/desa/en/news/population/2018-revision-of-world-urbanization-prospects.html (dostęp: 21.01.2021).

300 tys. maseczek trafi do szkót i przedszkoli, Biuro Edukacji m.st. Warszauy, https://edukacja. warszawa.pl/dla-ucznia-i-rodzica/bezpieczenstwo/22536-300-tys-maseczek-trafi-do-szkol-i-przedszkoli (dostęp: 20.04.2021). 